\title{
Concentrations of Polychlorinated Biphenyls (PCBs), Polychlorinated Dibenzo-p- dioxins and Furans (PCDD/Fs), and Polybrominated Diphenyl Ethers (PBDEs) as Functions of Sample Depth in Killer Whale (Orcinus orca) Blubber
}

\section{MICHAEL G. IKONOMOU ${ }^{1}$; SIERRA RAYNE ${ }^{2} *$ NORMAN F. CREWE ${ }^{1}$}

${ }^{I}$ Institute of Ocean Sciences, Fisheries and Oceans Canada, Sidney, British Columbia, Canada

${ }^{2}$ Chemistry, Earth \& Environmental Sciences, The University of British Columbia at Okanagan, Kelowna, British Columbia, Canada

\begin{abstract}
Concentrations of polychlorinated biphenyls (PCBs), polychlorinated dibenzo-p-dioxins and dibenzofurans (PCDD/Fs), and polybrominated diphenyl ethers (PBDEs) were examined as a function of depth in killer whale (Orcinus orca) blubber samples. Lipid-normalized concentrations of PCBs, PCDD/Fs, and PBDEs did not display significant variation with depth in three distinct blubber layers (outer, central, and inner). Significantly more variation in contaminant concentrations were observed with depth on a wet weight basis for the killer whale sample. The current study indicates that non-invasive microdart biopsy sampling methods commonly used for monitoring contaminants in marine mammals yield representative details on contaminant burdens for chlorinated and brominated aromatic compounds in marine mammal blubber, regardless of the quantity and type of blubber sampled, provided that lipid normalization is performed on resulting analytical determinations.@JASEM
\end{abstract}

Significant effort continues to be expended in the sampling and analysis of marine mammal blubber to assess the degree of anthropogenic contamination by inorganic and organic compounds. In particular, levels of polyhalogenated aromatic compounds (PHACs) are of concern because of their known persistence, propensity to bioaccumulate, and toxic properties. Studies near both populated and remote regions have repeatedly shown that tissues in top predators of the marine food chain contain PHACs at concentrations into the parts-per-million range (Tanabe et al., 1994; Loganathan and Kannan, 1994; Norstrom and Muir, 1994; Mossner and Ballschmiter, 1997). Many populations of marine mammals have also not yet recovered from the extensive harvesting activities of the 19th and 20th centuries (Brown and Lockyer, 1982; Wade, 1998; Read and Wade, 2000). Additional stressors such as the acute and chronic toxicity exerted by polychlorinated biphenyls (PCBs), dichlorodiphenyltrichloroethane (DDT) and its degradation products (e.g., DDE), and polychlorinated dibenzo- $p$-dioxins and dibenzofurans (PCDD/Fs) (Safe, 1990; Okey et al., 1994; Foster, 1995), among others, may only hinder or prevent recovery to historic populations. In regions such as the urbanized and industrialized Georgia Basin-Puget Sound (GB-PS; pop. $>5,000,000$ ) on the northwestern coast of North America, recent evidence suggests that the high levels of PCBs and other PHACs in a regional community of killer whales (Orcinus orca) may help explain their recent population declines (Ross et al., 2000; Rayne et al., 2004).

With such concerns, non-invasive sampling techniques are needed to monitor contaminant concentrations in marine mammals. Previous practices that used lethal methods to obtain blubber and tissue samples in these animals are no longer acceptable (Fossi et al., 1994; Dutton, 2002).
Additionally, the killing of an animal to determine contaminant concentrations prevents temporal monitoring of an individual to examine how pollutant levels change with age, life events (e.g., pregnancy and lactation in females), and anthropogenic inputs of contaminants. Without techniques that allow repeated sampling of an individual, insights into such underlying factors are difficult to elucidate because of the number of variables controlling contaminant levels and patterns, as well as the inherent variability within populations. To meet these needs, microdart biopsy systems have been developed for the sampling of blubber from marine mammals. Use of this type of system on three communities of killer whales from the GB-PS shed insights into concentrations and patterns of $\mathrm{PCBs}$, $\mathrm{PCDD} / \mathrm{Fs}$, polybrominated diphenyl ethers (PBDEs), polybrominated biphenyls (PBBs), and polychlorinated naphthalenes (PCNs) in these mammals (Ross et al., 2000; Rayne et al., 2004). However, rigorous calibration of the microdart technique was first necessary to ensure that reported concentrations were both accurate representations of contaminant burdens in killer whale blubber, and that these values could be compared to data from other studies.

Thus, a key consideration in sampling marine mammal blubber, as with other tissues, is obtaining a representative sample that is, ideally, not affected by sampling device, technique, or quantity. Microdarts may not fully penetrate the blubber of a marine mammal, and thus may only provide samples of contaminants in the outer layers. If differences in contaminant concentrations and patterns exist as a function of blubber depth, microdart biopsies may not be accurate reflections of whole blubber, or inferred whole body, contamination. Previous investigations have shown that differences in blubber composition (polarity, lipid weight, cell ordering and

* Corresponding author: phone: +1.250.490-9796; e-mail: raynesierra@yahoo.ca and raynes@agr.gc.ca. 
packing, and vascularization) and the region where the marine mammal is sampled (e.g., dorsal vs. ventral, anterior vs. posterior) (Lockyer et al., 1984, 1985), in addition to variations with depth of blubber (Ackman et al., 1965; Lockyer et al., 1984; Aguilar, 1985; Aguilar and Borrell, 1990, 1991) are factors to be considered during sampling. Hence, a mathematical transformation is needed to account for such variation to ensure concentration values reported are indicative of the true contaminant burden residing within the mammal. Lipid normalization appears to offer such a tool, whereby contaminant concentrations quantified on a wet weight tissue basis are divided by the percent lipids of which the tissue is composed. Prior work has shown lipid normalization of contaminant concentrations is able to remove much of the variation in levels between differing tissues such as blubber, liver, and muscle (Aguilar, 1985; Gauthier et al., 1997) [34, 36-39], and pharmacokinetic studies have demonstrated a relatively rapid equilibrium distribution of lipophilic contaminants (Matthews, 1983). Thus, by knowing the approximate percent lipid weight of an entire organism, representative sampling and contaminant analysis followed by lipid normalization in whatever tissue was sampled can allow an inference of contaminant levels in other tissues and the total body burden. In the present work, we investigated the distribution in quantities of four major contaminant classes - PCBs, PCDD/Fs, and PBDEs - as a function of depth in a killer whale blubber sample to determine if such whole body approximations based on varying quantities and qualities of blubber samples were valid.

\section{MATERIALS AND METHODS}

Sample Collection: The killer whale (Orcinus orca) sample was obtained from a dead 56 year old female member of the northern resident community of these marine mammals from the Strait of Georgia in British Columbia, Canada. Collection of the sample occurred within one week of death. Necropsy and sampling were carried out within two weeks of death. The animal appeared to have died abruptly, possibly from cardiac failure, as evidenced by a stomach full of fish and appeared to be in good body condition. Tissues were overly autolyzed for any useful histology to be carried out, although the lungs, liver, and kidneys appeared normal. The sample was collected from the region anterior to the dorsal fin in the saddle patch area.

Sample Processing: The killer whale sample was visually inspected prior to experimentation. Three distinct blubber layers were evident: outer, central, and inner. Three replicate microdart biopsies were fired into the sample according to methods described elsewhere (Barrett-Lennard et al., 1996). The depth of dart penetration was ca. 20-25 mm. Prior to analysis, the dart samples were trimmed of the overlying skin layer and the first $2-3 \mathrm{~mm}$ of the outer blubber layer. Microdart samples contained mostly outer and central blubber tissues. Wet weight masses of $0.227 \mathrm{~g}, 0.215 \mathrm{~g}$, and $0.229 \mathrm{~g}$, were obtained for the three samples. Lipid weights for each sample were $0.166 \mathrm{~g}, 0.146 \mathrm{~g}$, and, $0.149 \mathrm{~g}$, respectively, corresponding to lipid compositions of $73.1 \%$, $67.9 \%$, and $65.1 \%$. Individual $0.2 \mathrm{~g}$ samples were also taken from each of the blubber layers by sectioning the outer blubber layer $(0-7 \mathrm{~mm}$ depth from skin surface), the central blubber layer (10-16 $\mathrm{mm}$ depth from skin surface), and inner blubber layer (22-27 mm depth from skin surface). The total thickness of killer whale blubber from skin surface to the underlying muscle layer was $27 \mathrm{~mm}$. A $2.5 \mathrm{~g}$ composite killer whale blubber sample was also obtained from the outer, central, and inner blubber layers by sectioning through all three layers at a $90^{\circ}$ angle to the outer skin surface.

Following processing, all samples were immediately wrapped in solvent rinsed aluminum foil, placed in solvent rinsed amber glass jars with aluminum foil covered Teflon caps, and frozen at $-20^{\circ} \mathrm{C}$ prior to sample extraction, cleanup, and analysis as described below.

Sample Extraction and Cleanup: Each sample was weighed and then transferred quantitatively to a mortar with ca. $100 \mathrm{~g}$ of anhydrous $\mathrm{Na}_{2} \mathrm{SO}_{4}$ and spiked with ${ }^{13} \mathrm{C}$-labeled internal standards for PCBs, $\mathrm{PCDD} / \mathrm{Fs}$, and PBDEs as described elsewhere (Ikonomou, 2001). The mixture was ground until homogenous and transferred to a glass extraction column packed with glass wool. Samples were eluted with $100 \mathrm{~mL}$ of $1: 1 \mathrm{CH}_{2} \mathrm{Cl}_{2}$ :hexane and the eluant reduced to just dryness by rotary evaporation at room temperature. Sample weights were recorded once a consistent weight was achieved. Percent lipid was calculated using the following equation: \% lipid $=($ mass of lipid/mass of sample $) \times 100 \%$. All samples were processed in batches of 12 which consisted of a procedural blank and a reference material. The recoveries of the ${ }^{13} \mathrm{C}$-labelled $\mathrm{PCB}$, $\mathrm{PCDD} / \mathrm{F}$, and PBDE surrogates ranged from 40$120 \%$. Congener concentrations presented below are corrected for percent recovery of the internal standards.

HRGC-HRMS Analysis: Analyses of clean blubber extracts were performed by HRGC-HRMS using a Micromass VG-Autospec high resolution mass spectrometer equipped with a Hewlett-Packard model 5890 Series II gas chromatograph. Samples were analyzed for 142 PCB congeners, all 2,3,7,8substituted $\mathrm{PCDD} / \mathrm{F}$ congeners, and 37 individual PBDE congeners from mono- through hexa- 
brominated. Details on specific congener identities, the HRGC-HRMS conditions, and the QA/QC protocols for the multi-residue ultra-trace analysis of these analytes are given elsewhere (Ikonomou, 2001; Ikonomou et al., 2002a, 2002b).

\section{RESULTS AND DISCUSSION}

Lipid normalized concentrations of PCBs, PCDD/Fs, and PBDEs from $0.2 \mathrm{~g}$ individual samples in each of three distinct blubber layers (outer, central, and inner) from the killer whale blubber sample, as well as three replicate $0.2 \mathrm{~g}$ microdart samples obtained from a cross-section of the three blubber layers, display significantly less variation when plotted against a 2.5 g homogenized composite cross-sectional sample of all three blubber layers than when the data is presented on a wet weight basis (Figure 1). A reduction in variation compared to the $2.5 \mathrm{~g}$ composite samples is made by an examination of the vertical distance between the individual sample concentration and the 1:1 line shown in Figure 1.
Contaminant concentrations for the individual congeners and totals for each compound class over which these findings are evident range up to nine orders of magnitude. In Figure 1, data points falling on the 1:1 line indicate that the sample of interest (even if obtained in only a $0.2 \mathrm{~g}$ sample from a single blubber layer) can be accurately used to assess contamination in a larger 2.5 composite blubber sample containing all three blubber layers. Any small amount of variation remaining in the lipid-normalized concentrations of each congener between layers is likely due to errors arising from the difficulty in measuring percent lipids in the small size samples (ca. 0.1-0.2 g) used in this study. These findings appear to support the use of lipid normalization as a technique for comparing contaminant concentrations within differentiated tissues in a marine mammal, and also remove some of the concerns resulting from different sampling techniques between and within research groups, as well as the quality and nature of tissue

sample
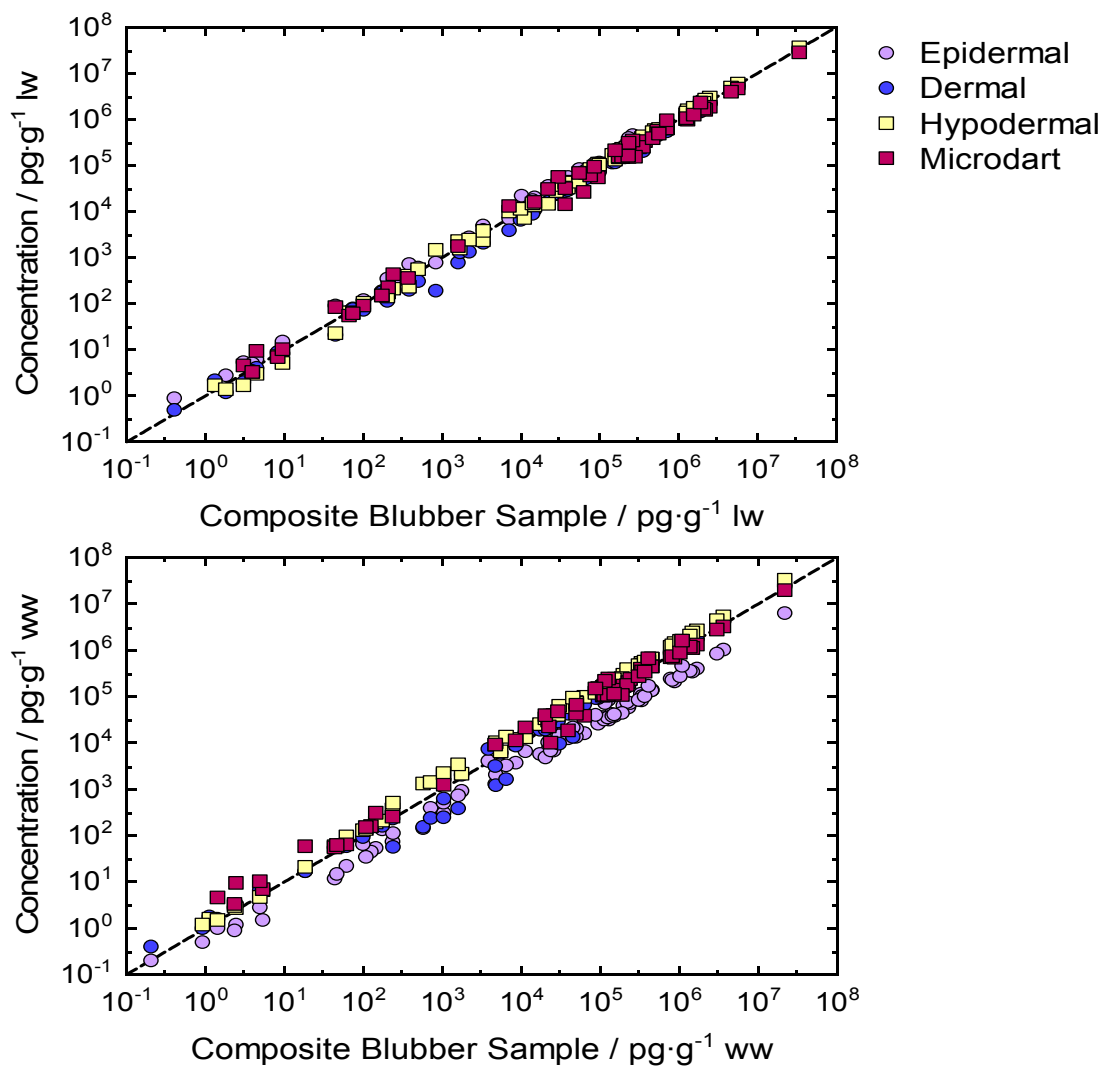

Fig. 1: Concentrations of individual PCB, 2,3,7,8-substituted PCDD/F, and PBDE congeners and the totals for each contaminant class in individual $0.2 \mathrm{~g}$ samples collected from the skin, outer blubber, and inner blubber layers, and average concentrations ( $\pm 95 \% \mathrm{CL})$ from three replicate $0.2 \mathrm{~g}$ microdart samples through all three layers, plotted against concentrations in a $2.5 \mathrm{~g}$ homogenized cross-sectional composite sample of all three blubber layers from a killer whale (Orcinus orca) sample on both lipid weight (a) and wet weight (b) bases. A 1:1 line is shown to aid in comparisons. 
The $2.5 \mathrm{~g}$ composite killer whale sample was obtained from the outer, central, and inner blubber layers by sectioning through all three layers at a $90^{\circ}$ angle to the outer skin surface and analyzing for PCBs, PCDD/Fs, and PBDEs. These types of samples, and the resulting contaminant concentrations, are what would be expected if the layers were not analyzed separately but were rather homogenized into a single sample, or where a "perfect" microdart biopsy was obtained in the field. As shown in Figure 1, variations in lipid normalized $\mathrm{PCB}, \mathrm{PCDD} / \mathrm{F}$, and PBDE concentrations from each layer about this composite sample are modest, and suggest that a sample from any combination of blubber layers (including a single layer such as the epidermis) will provide a reasonable insight into the true quantity of lipid normalized contaminant residing in the blubber. Thus, it appears that reproducibility in blubber sampling technique, sample size, and quality are not, to a first approximation, critical to assessing $\mathrm{PCB}, \mathrm{PCDD} / \mathrm{F}$, and PBDE concentrations in marine mammals provided the resulting values are lipid normalized. Similar validations in the use of lipid normalization to remove contaminant concentration variations between marine mammal blubber layers, as well as for the use of microdart-type blubber biopsies versus larger gram-scale samples, have been previously reported for PCBs and organochlorine pesticides (Gauthier et al., 1997). However, the present study extends such validation to PCDD/Fs and PBDEs, both of which have the additional presence of arylether linkages which could effect transport and partitioning within blubber, as well as to a new species of marine mammal (i.e., killer whales).

This observed lack of significant variation in lipid normalized concentrations of $\mathrm{PCBs}, \mathrm{PCDD} / \mathrm{Fs}$, and PBDEs with depth in killer whale blubber suggests that when analytical results from these mammals are lipid normalized, the quantity and type of blubber sampled does not appear to significantly influence the acquisition of representative insights into PHAC concentrations and patterns. Hence, while standardization of sampling techniques is desired, such standardization may not be necessary to confidently compare concentrations and patterns of PHACs between different sampling methods. Rather, the focus is on the optimization and standardization of analytical methods (from sample processing through to instrumental analysis) to ensure that the quantities of analyte reported are consistent among different groups.

The current study suggests that microdart biopsy sampling methods yield representative details on contaminant burdens for chlorinated and brominated aromatic compounds in marine mammal blubber. To our knowledge, this is the first time a microdart biopsy sampling method has been validated for PCDD/Fs and PBDEs. Overall, it appears as though such contaminant levels, when lipid normalized, are both qualitatively and quantitatively uniform with depth. This facilitates the use of non-invasive techniques such as microdart biopsies, which may not penetrate the full depth of blubber depending on impact angle and may have differing contributions of various blubber layers, as reliable indicators of contaminant concentrations in marine mammal blubber.

Acknowledgment: We thank T.G. Smith, G.M. Ellis, and L.G. Barrett-Lennard for providing the blubber samples. Special thanks to Jim Borrowman of Stubbs Island Whale Watching and the killer whale necropsy team for providing details for the KW-A9 sample. The assistance of M. Fischer with data organization and analysis, and the Regional Dioxin Laboratory staff for sample analyses and technical assistance, is much appreciated. The project was funded by DFOPAC allocations to the RDL.

\section{REFERENCES}

Ackman, R G; Eaton, C A; Jangaard, P M (1965). Lipids of the fin whale (Balaenoptera physalus) from North Atlantic waters: fatty acid composition of whale blubber and blubber sections. Can J Biochem 43:1513-1520

Aguilar, A (1985). Compartmentation and reliability of sampling procedures in organochlorine pollution surveys of cetaceans. Res Rev 95:91114.

Aguilar, A; Borrell, A (1990). Patterns of lipid content and stratification in the blubber of fin whales (Balaenoptera physalus). J Mammalogy 71:544-554

Aguilar, A; Borrell, A (1991). Heterogenous distribution of organochlorine contaminants in the blubber of baleen whales: implications for sampling procedures. Mar Environ Res 31:275286

Barrett-Lennard, L G; Smith, T G; Ellis, G M (1996). A cetacean biopsy system using lightweight pneumatic darts, and its effect on the behaviour of killer whales. Mar Mammal Sci 12:14-27

Brown, S; Lockyer, C (1982). Some effects of whaling on the population biology of whales. Biol J Linn Soc 18:407

Dutton, M D (2002). The use of fish blood for biomonitoring. SETAC Globe 3:30-32 
Fossi, M C; Leonzio, C; Peakall, D B (1994) The use of nondestructive biomarkers in the hazard assessments of vertebrate populations. In: Leonzio C (ed) Nondestructive Biomarkers in Vertebrates. Lewis Publishers, Chelsea, MI, USA. p. 3-434

Foster, W G (1995) The reproductive toxicology of Great Lakes contaminants. Environ Health Perspect 103:63-69

Gauthier, J M; Metcalfe, C D; Sears, R (1997). Validation of the blubber biopsy technique for monitoring of organochlorine contaminants in balaenopterid whales. Mar Environ Res 43: 157179

Ikonomou, M G (2001). A comprehensive multiresidue ultra-trace analytical method, based on HRGC/HRMS, for the determination of PCDDs, PCDFs, PCBs, PBDEs, PCDEs, and organochlorine pesticides in six different environmental matrices. Fisheries and Oceans Canada, Sidney, BC, Canada.

Ikonomou, M G; Rayne, S; Addison, R F (2002a). Exponential increases of the brominated flame retardants, polybrominated diphenyl ethers, in the Canadian arctic from 1981 to 2000 . Environ Sci Technol 36:1886-1892

Ikonomou, M G; Rayne, S; Fischer, M; Fernandez, M P; Cretney, W (2002b). Occurrence and congener profiles of polybrominated diphenyl ethers (PBDEs) in environmental samples from coastal British Columbia, Canada. Chemosphere 46:649-663

Lockyer, C H; McConnell, L C; Waters, T D (1984). The biochemical composition of fin whale blubber. Can J Zool 62:2553-2562

Lockyer, C H; McConnell, L C; Waters, T D (1985). Body condition in terms of anatomical and biochemical assessment of body fat in North Atlantic fin and sei whales. Can J Zool 63:23282338

Loganathan, B G; Kannan, K (1994). Global organochlorine contamination trends - an overview. Ambio 23:187-191

Matthews, H B (1983). Metabolism of PCBs in mammals: routes of entry, storage, and excretion: In D'Itri FM; Kamrin, MA (eds) PCBs: Human and Environmental Hazards. Butterworth Publishers, Toronto, Canada, p. 443
Mossner, S; Ballschmiter, K (1997). Marine mammals as global pollution indicators for organochlorines. Chemosphere 34:1285-1296

Norstrom, R J; Muir D C G (1994). Chlorinated hydrocarbon contaminants in arctic marine mammals. Sci Total Environ 154:107-128

Okey, A B; Riddick, D S; Harper, P A (1994). Molecular biology of the aromatic hydrocarbon (dioxin) receptor. Trends Pharmacol Sci 15:226232

Rayne, S; Ikonomou, M G; Ross P S; Ellis, G M; Barrett-Lennard, G (2004) PBDEs, PBBs, and $\mathrm{PCNs}$ in three communities of free-ranging killer whales (Orcinus orca) from the

northeastern Pacific Ocean. Environ Sci Technol 38:4293-4299

Read, A J; Wade, P R (2000). Status of marine mammals in the United States. Conserv Biol 14:929-940

Ross P S; Ellis, G M; Ikonomou, M G; BarrettLennard, G; Addison R F (2000) High PCB concentrations in free-ranging Pacific killer whales, Orcinus orca: Effects of age, sex and dietary preference. Mar Poll Bull 40:504-515

Safe, S (1990). Polychlorinated biphenyls (PCBs), dibenzo- $p$-dioxins (PCDDs), dibenzofurans (PCDFs), and related compounds environmental and mechanistic considerations which support the development of toxic equivalency factors (TEFs). Crit Rev Toxicol 21:51-88

Tanabe, S; Iwata, H; Tatsukawa, R (1994). Global contamination by persistent organochlorines and their ecotoxicological impact on marine mammals. Sci Total Environ 154:163-177

Wade, P R (1998). Calculating limits to the allowable human-caused mortality of cetaceans and pinnipeds. Mar Mammal Sci 14:1-37 